\title{
Observations of Habitat Use by Polar Bears, Ursus maritimus, in the Alaskan Beaufort, Chukchi, and Northern Bering Seas
}

\author{
DONALD J. HANSEN
}

U.S. Department of the Interior, Minerals Management Service, 949 E. $36^{\text {th }}$ Avenue, Anchorage, Alaska 99504 USA

Hansen, Donald J. 2004. Observations of habitat use by Polar Bears, Ursus maritimus, in the Alaskan Beaufort, Chukchi, and northern Bering Seas. Canadian Field-Naturalist 118(3): 395-399.

A total of 1112 Polar Bears (Ursus maritimus) at 482 sightings were recorded during aerial surveys in the Beaufort, Chukchi, and northern Bering Seas conducted primarily during September and October from 1979-1999. Of these bears, 784 were observed offshore at 400 sightings. The surveys were conducted by the Naval Ocean Systems Center and Minerals Management Service; they were designed to monitor the fall Bowhead Whale (Balaena mysticetus) migration. Over the 20-year period, 1096620 kilometers of surveys were flown. The majority of the offshore Polar Bears, 595 bears at 290 sightings, and most of the kill sites and polar bear tracks were recorded in $80-100 \%$ ice cover. The number of bears per kilometer increased substantially in $>24 \%$ ice cover, with the highest number observed in $80-100 \%$ ice cover. This habitat use probably is related to the availability of seals, their primary prey. There were 328 bears ( 83 sightings) recorded on land, and most of them were associated with whale carcasses and bowhead whale subsistence harvest sites along the Alaskan Beaufort Sea coast.

Key Words: Polar Bear, Ursus maritimus, habitat, Beaufort Sea, Chukchi Sea, Northern Bering Sea, Alaska.

The preference of Polar Bears for extensive ice habitats is well documented (Stirling et al. 1993; Stirling and Derocher 1993; Amstrup 1995). Polar Bears need an ice platform to hunt successfully for seals, their primary prey (Stirling, Andriashek, and Calvert 1993). The bears select ice habitats that increase accessibility (availability) of seals. Ferguson et al. (2000) compared ice-habitat use by Polar Bears of the Canadian Arctic Archipelago and Baffin Bay. They found ice-habitat use to be similar for the two regions. However, Baffin Bay bears had more limited access to Ringed Seals (Phoca hispida) because of the complete absence of ice cover during the summer season. The Canadian Arctic Archipelago had more consistent seasonal ice cover, which provided the bears with reliable access to the seals. Although the Baffin Bay region had a much higher density of Ringed Seals (1.4-2.1 seals/square kilometer: Finley et al. 1983; Stirling and Oritsland 1995) than the Arctic Archipelago region (0.28-0.97seals/square kilometer: Kingsley, Stirling, and Calvert 1985), both regions had very similar Polar Bear densities. Ferguson et al. (2000) concluded that Polar Bear abundance is not always proportional to prey density because of differences in Polar Bear access to seals (i.e., availability of prey).

During September and October (open-water season), the Alaskan Beaufort Sea has great variability in ice coverage from year to year (Figures $1 \mathrm{a}$ and $1 \mathrm{~b}$ ). Like Baffin Bay, the Arctic coast of Alaska during light ice years is free of ice during the open-water season, when the pack ice is more than 100 miles from the coast (see Figure 1a). During the absence of ice in coastal Beaufort Sea habitats, bears that occur along the coast either scavenge on animal carcasses that wash ashore, feed on the remains of whale carcasses at subsistence whale harvest sites, or fast until shorefast ice forms and seals become available (United States Department of the Interior, Fish and Wildlife Service 1995).

During heavy ice years, the pack ice remains on the continental shelf; ice floes are common in coastal waters, and shorefast ice remains or forms early during the fall (Figure 1b). These varying ice conditions affected the movements and distribution of Polar Bears in the Beaufort and Chukchi seas (Amstrup 2000).

\section{Methods and Materials}

From 1979-1999, the Naval Ocean Systems Center under contract with the Bureau of Land Management (1979-1982) and Minerals Management Service (19821999) under the Bowhead Whale Aerial Survey Project has conducted aerial surveys in the Beaufort, Chukchi, and Bering seas (Ljungblad et al. 1986; Moore and Clarke 1992; Treacy 2000) to monitor the fall migration (late August through October) of endangered whales (Treacy 2000). Information on Polar Bears and sea-ice coverage was acquired mostly from these aerial surveys. Surveys were flown primarily at 1500 feet (458 meters), weather permitting, or at a minimum of 1000 feet (305 meters) to avoid disturbing marine mammals. The aircraft used was a de Havilland Twin Otter Series 300 with bubble windows on both sides of the plane. Earlier flights (1979-1991) over the northern Bering, Chukchi, and western Beaufort seas used a Grumman Turbo Goose model G21G (Ljungblad et al. 1986; Moore and Clarke 1992).

Information also was used from aerial whale surveys conducted during the spring and summer (April through August) in the northern Bering Sea as well 


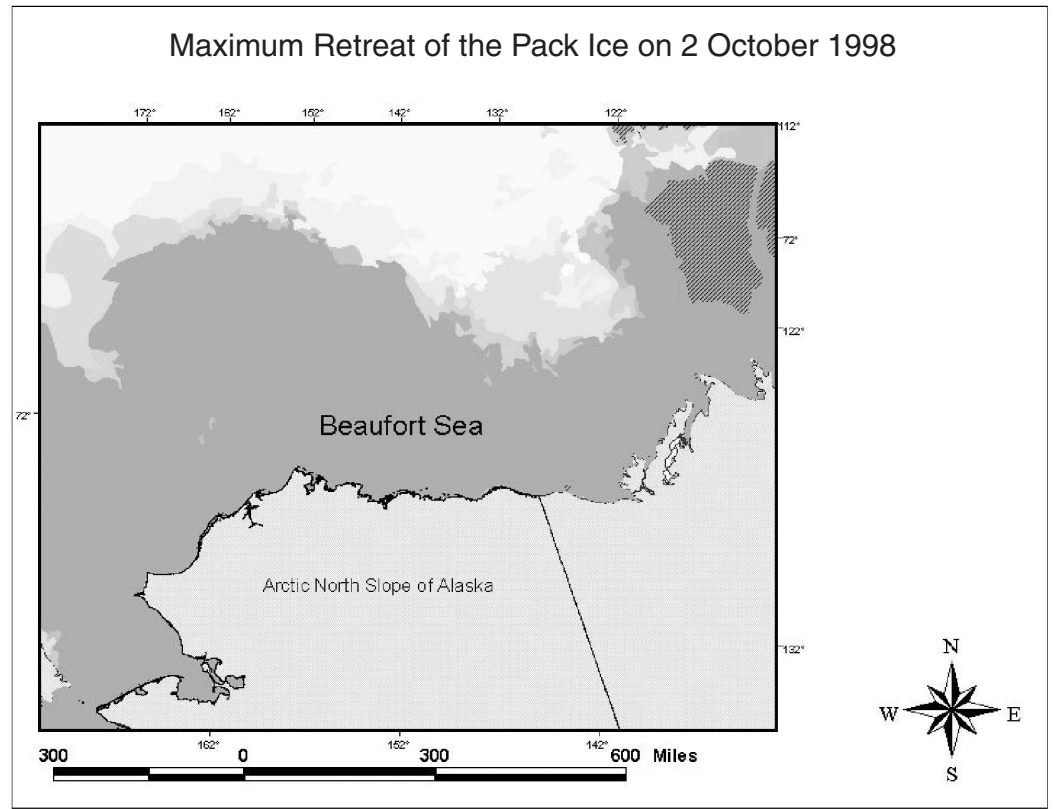

FIGURE 1a. Light Ice Year Information derived from the National Naval Ice Center (http://www.natice.noaa.gov/westarct1.htm).

Maximum Retreat of the Pack Ice on 18 September 1983

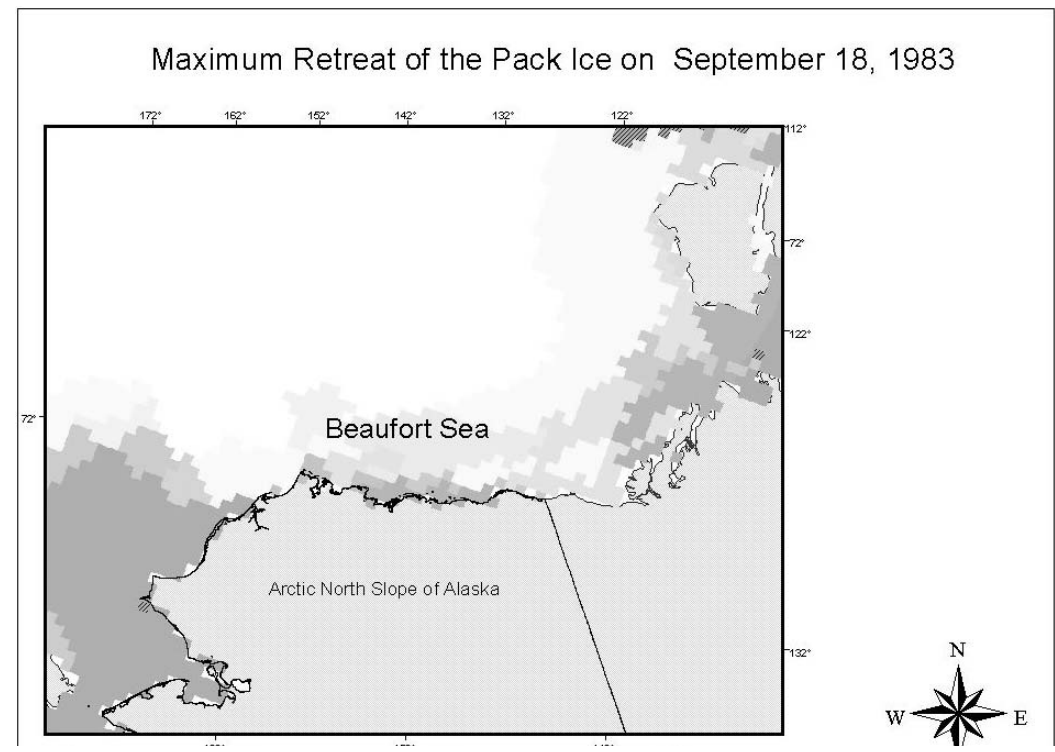

FIGURE 1b. Heavy Ice Year information derived from the National Naval Ice Center (http://www.natice.noaa.gov/westarct1.htm).

as in the Chukchi and Beaufort seas (Ljungblad et al. 1986; Moore and Clarke 1992). Incidental sightings of Polar Bears and their behavior were recorded along north-south transects and off transects along the re- mainder of the flight tracks (Figure 2). Information was recorded on percent ice coverage within about 12 kilometers of the aircraft at each position update (once about every 5 minutes) and at each sighting loca- 


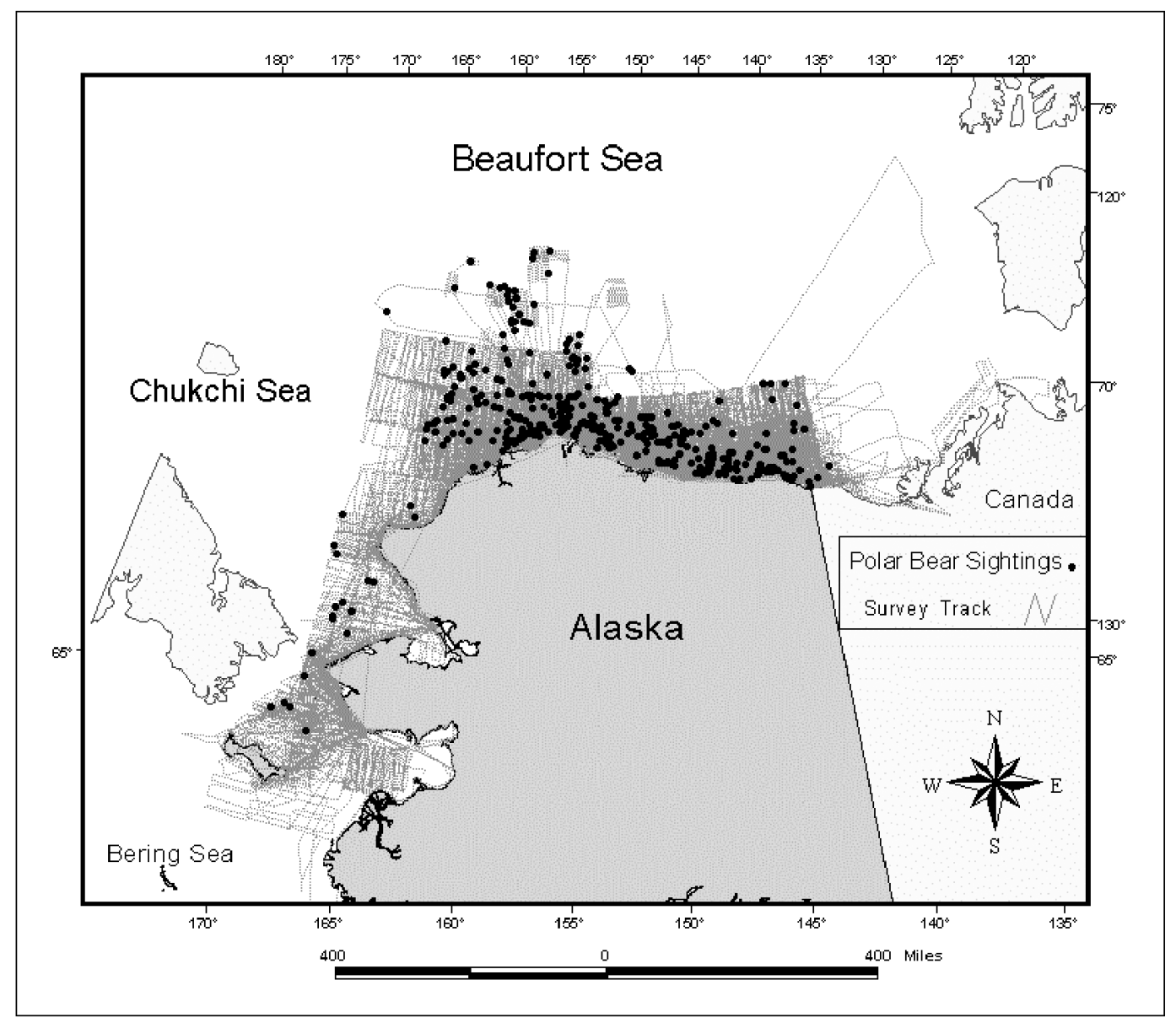

FIGURE 2. Study are with survey tracks and Polar Bear sightings.

tion. Position updates, sighting locations, and icecoverage data were recorded on an onboard computer system connected to a Global Positioning System receiver in the aircraft. These records included information on numbers of Polar Bears per sighting and ice cover within about 1-2 kilometers of the aircraft. Polar Bear tracks and kill sites also were recorded during September and October from 1987 through 1999.

Survey effort in the Beaufort Sea focused primarily along the coast, continental shelf, and shelf break, while surveys in the northern Bering and eastern Chukchi seas extended from the coast to the International Date Line (Figure 2). The Polar Bear sightings, kill sites, locations of bear tracks, and ice-coverage data were converted into database files and analyzed with Arcview Geographic Information System Program 3.2a (developed by ESRI in Redland, Calif.). Tables and graphs were created in Microsoft Word and Microsoft Excel (Windows 2000) to compare bear numbers and sight- ings with ice coverage (Table 1 and Figure 3 ) and kill sites and bear tracks with ice cover (Figures 4 and 5). The number of bear sightings and the survey effort (kilometers flown) were plotted by ice category to compare ice-cover use (Figure 2). This analysis is providing useful information on habitat use by Polar Bears occurring in Alaskan waters.

\section{Results and Discussion}

Table 1 shows the number of Polar Bears and number of sightings recorded offshore by ice cover and on the mainland or on barrier islands. Figure 4 shows the number of Polar Bear kill sites and ice coverage recorded at the kill locations. Figure 5 shows the numbers of Polar Bear tracks recorded and ice coverage at their locations.

Over the 20-year period and the 1096620 kilometers of surveys flown, 1112 Polar Bears at 482 sightings were recorded in the Beaufort, Chukchi, and Bering 
TABLE 1. Number of Polar Bears and Number of Sightings (Recorded Per Year) by Ice Coverage and Number Recorded on Land.

\begin{tabular}{|c|c|c|c|c|c|c|c|c|c|}
\hline \multirow{2}{*}{$\begin{array}{l}\text { Year } \\
1979\end{array}$} & \multicolumn{2}{|c|}{$\begin{array}{l}80-100 \% \text { Ice } \\
\text { Ice }\end{array}$} & $\begin{array}{l}50-79 \% \\
\text { Ice }\end{array}$ & $\begin{array}{l}25-49 \% \\
\text { Ice }\end{array}$ & $\begin{array}{l}1-24 \% \\
\text { Ice }\end{array}$ & No Ice & \multirow[t]{2}{*}{ On Land } & \multicolumn{2}{|c|}{$\begin{array}{l}\text { Total Number of } \\
\text { Bears and Sightings }\end{array}$} \\
\hline & 15 & $(8)$ & & & & $5 \quad(2)$ & & 20 & (10) \\
\hline 1980 & 29 & (21) & 1 & $13 \quad(5)$ & 4 (2) & & & 47 & (29) \\
\hline 1981 & 50 & (15) & $3 \quad(2)$ & 12 (1) & 4 (2) & & & 69 & (20) \\
\hline 1982 & 16 & (13) & $4 \quad$ (4) & 1 (1) & & 1 (1) & & 22 & (19) \\
\hline 1983 & 76 & (35) & 14 (11) & 3 (3) & & & & 93 & (49) \\
\hline 1984 & 23 & (15) & $5 \quad(2)$ & 3 (2) & 3 (2) & 1 (1) & & 35 & (22) \\
\hline 1985 & 5 & (3) & 1 & & & & & 6 & (4) \\
\hline 1986 & 9 & (6) & 3 (2) & & 3 (2) & & & 15 & (10) \\
\hline 1987 & 4 & (2) & 1 (1) & & & & & 5 & (3) \\
\hline 1988 & 69 & (43) & 1 (1) & 2 (2) & & & & 72 & (46) \\
\hline 1989 & 15 & (10) & 11 & $6 \quad(5)$ & $5 \quad(3)$ & & & 37 & (25) \\
\hline 1990 & 52 & (40) & 1 (1) & & & & & 53 & (41) \\
\hline 1991 & 22 & (13) & $4 \quad(2)$ & 1 (1) & 1 (1) & 1 (1) & & 29 & (18) \\
\hline 1992 & 105 & (31) & 31 (12) & & & & $67 \quad(5)$ & 203 & (48) \\
\hline 1993 & & & & 3 (1) & 2 (2) & & & 5 & (3) \\
\hline 1994 & 26 & (12) & 2 (1) & 3 (2) & 1 (1) & & & 32 & (16) \\
\hline 1995 & & & & 2 (1) & 3 (1) & & & 5 & (2) \\
\hline 1996 & 9 & (7) & & 1 (1) & & & & 10 & (8) \\
\hline 1997 & 53 & (8) & & 1 (1) & & & 11 (2) & 65 & (11) \\
\hline 1998 & 15 & (6) & $9 \quad(4)$ & 1 (1) & & $8 \quad(5)$ & $217(57)$ & 247 & (73) \\
\hline 1999 & 2 & (2) & & 1 (1) & & 3 (3) & 33 (19) & 39 & (25) \\
\hline Totals: & 595 & $(290)$ & $91(52)$ & $45(23)$ & 28 (17) & $25 \quad(17)$ & $328(83)$ & 1112 & (482) \\
\hline
\end{tabular}

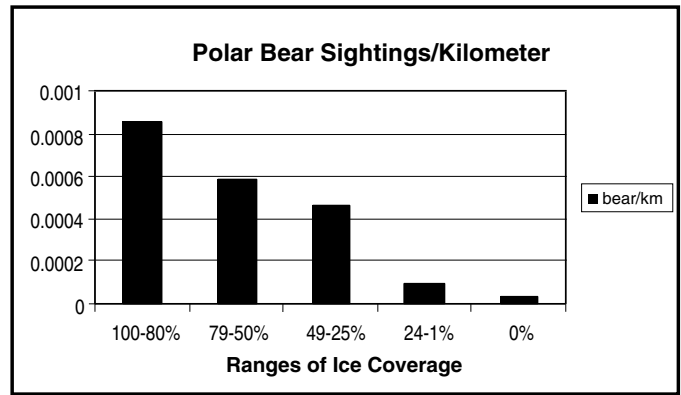

Figure 3. Polar Bear sightings per kilometer recorded from April 1979 through October 1999 in the Beaufort, Chukchi and Bering Seas.

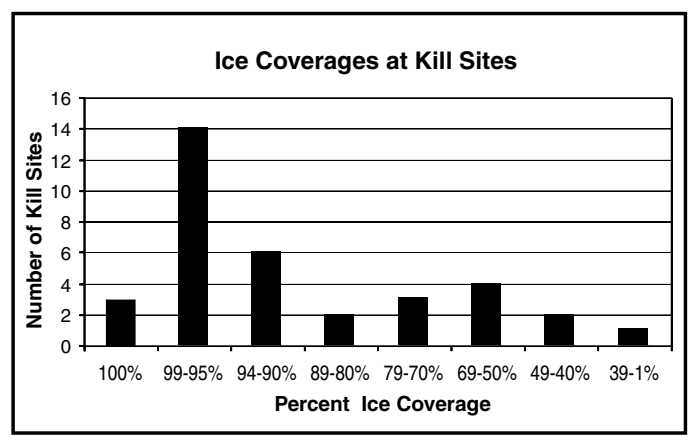

FIGURE 4. Number of kill sites and ice coveage recorded at each site. seas from 1979-1999 (Table 1). Of these bears, 784 were observed offshore at 400 sightings. Figure 2 shows the number of Polar Bears per kilometer of survey effort over ranges of ice coverage. The number of bears per kilometer increased substantially in $>24 \%$ ice cover, with the highest number observed in $80-100 \%$ ice cover. These observations suggest that Polar Bears may use $80-100 \%$ ice cover more often than lower percentages of ice cover. This habitat use probably is related to the availability of seals, their primary prey. Table 1 lists the number of bears and sightings seen offshore in other ice concentrations. Thirtyfive kill sites and 769 Polar Bear track sightings were recorded, mostly in $80-100 \%$ ice cover (Figures 3 and 4 , respectively). Tracks with zero ice cover were recorded on land or barrier islands.

A total of 328 bears (at 83 sightings) were recorded on the mainland or on barrier islands (Table 1). Most of these bears were associated with whale carcasses and bowhead whale subsistence harvest sites along the Beaufort Sea coast. The large numbers of bears were recorded on land in 1992 (67 bears) and 1998 (217 bears), when repeat sightings were made of several bears feeding on whale carcasses along the Beaufort Sea coast (Table 1).

Studies of radio- and satellite-tagged Polar Bears have provided useful information on the movements and habitat use of individual Polar Bears (Arthur et al. 1996; Ferguson et al. 1998; Amstrup et al. 2001; Durner et al. 2004). These studies recorded Polar Bear locations and compared them with satellite-derived, 


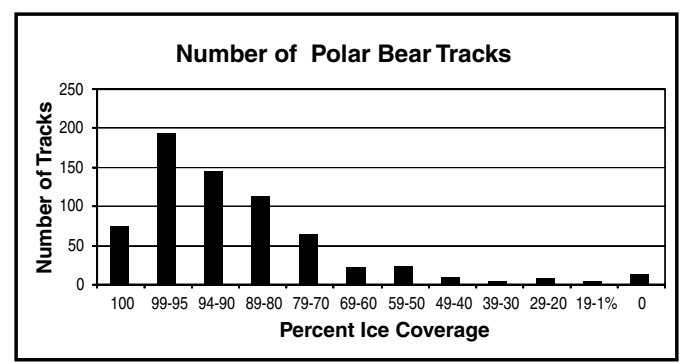

FiguRE 5. Number of Polar Bear tracks and ice coverage recorded at each site.

digitized maps of ice types and ice concentrations in the general areas where the bears were located. These remote-sensing techniques provide general information on habitat use by Polar Bears throughout the year. Aerial surveys in this study recorded ice types and ice concentrations within 1-2 kilometers of the aircraft along the flight track and at the specific locations where Polar Bears were observed. Both techniques record information on habitat use. Aerial surveys provide real-time information on habitat use at the actual locations where the bears were observed, while remote-sensing techniques provide valuable information on bear movements and general information on habitat use over time.

Many aerial surveys conducted specifically for Polar Bears are flown at lower altitudes than the 1500 foot surveys conducted in this study. Aerial surveys that are conducted at very low altitudes (200-300 feet) are very likely to disturb Polar Bears and other wildlife. Our surveys were conducted at 1500 feet to avoid disturbing marine mammals. Even at 1500 feet some of the bears observed reacted to the aircraft by running away when the aircraft past overhead. Polar Bears are quite visible on the ice at 1500 feet because their tracks are very detectable. Other marine mammals of comparable size to Polar Bears, such as Beluga Whales, are easily detected at 1500 feet.

\section{Acknowledgments}

This study was funded by the U.S. Department of the Interior, Minerals Management Service, as part of its Alaska Environmental Studies Program. As the Principal Investigator, I would like to thank Stephen Treacy, Project Manager for the Minerals Management Service Bowhead Whale Aerial Survey Project, for providing the survey data on Polar Bears and ice coverage along the survey tracks from 1979 through 2000, and for his comments on the draft manuscript. I also would like to thank Elinore M. Anker, who edited the manuscript.

\section{Literature Cited}

Amstrup, S. C. 1995. Movements, distribution, and population dynamics of Polar Bears in the Beaufort Sea. Ph.D. thesis.
University of Alaska, Fairbanks, Fairbanks, Alaska. 299 pages.

Amstrup, S. C. 2000. Polar Bear. Pages 133-157 in Chapter 7 in The natural history of an Arctic oil field development and the biota. Edited by J. C. Truett and S. R. Johnson. Academic Press, San Diego, California.

Amstrup, S. C., G. M. Durner, T. L. McDonald, D. M. Mulcahy, and G. W. Garner. 2001. Comparing movement patterns of satellite-tagged male and female Polar Bears. Canadian Journal of Zoology 79: 2147-2158.

Arthur, S. M., B. F. J. Manly, L. L. McDonald, and G. W. Garner. 1996. Assessing habitat selection when availability changes. Ecology 77: 215-227.

Durner, G. M., S. C. Amstrup, R. Neilson, and T. McDonald. 2004. The use of sea ice habitat by female Polar Bears in the Beaufort Sea. OCS Study MMS 2004-014. USDOI, MMS, Alaska OCS Region, Anchorage, Alaska. 41 pages.

Ferguson, S. H., M. K. Taylor, and F. Messier. 2000. Influence of sea ice dynamics on habitat selection by Polar Bears. Ecology 81: 761-772.

Ferguson. S. H., M. K. Taylor, E. W. Born, and F. Messier. 1998. Fractals, sea-ice landscape and special patterns of Polar Bears. Journal of Biogeography 25: 1081-1092.

Finley, K. J., G. W. Miller, R. A. Davis, and W. R. Koski. 1983. A distinctive large breeding population of Ringed Seals (Phoca hispida) inhabiting the Baffin Bay pack ice. Arctic 36: 162-173.

Kingsley, M. C. S., I. Stirling, and W. Calvert. 1985. The distribution and abundance of seals in the Canadian high Arctic, 1980-1985. Canadian Journal of Fisheries and Aquatic Science 42: 1189-1210.

Ljungblad, D. K., S. E. Moore, J. T. Clarke, and J. C. Bennett. 1986. Aerial surveys of endangered whales in the northern Bering, eastern Chukchi, and Alaskan Beaufort Seas, 1985: with a seven year review, 1979-85. OCS Study, MMS 86-0002. USDOI, MMS, Alaska OCS Region, Anchorage, Alaska. 142 pages.

Moore, S. E., and J. T. Clarke. 1992. Distribution, abundance, and behavior of endangered whales in the Alaskan Chukchi and western Beaufort Seas, 1991: with a review 1982-91. OCS Study, MMS 92-0029. USDOI, MMS, Alaska OCS Region, Anchorage, Alaska. 126 pages.

Stirling, I., and A. E. Derocher. 1993. Possible impacts of climatic warming on Polar Bears. Arctic 46: 240-245.

Stirling, I., D. Andriashek, and W. Calvert. 1993. Habitat preferences of Polar Bears in western Canadian Arctic in late winter and spring. Polar Record 29(168): 13-24.

Stirling, I., and N. A. Oritsland. 1995. Relationships between estimates of Ringed Seal (Phoca hispida) and Polar Bear (Ursus maritimus) populations in the Canadian Arctic. Canadian Journal of Fisheries and Aquatic Sciences 52: 2594-2612.

Treacy, S. D. 2000. Aerial surveys of endangered whales in the Beaufort Sea fall 1998, and 1999. OCS Study, MMS 2000-066. USDOI, MMS, Alaska OCS Region, Anchorage, Alaska. 135 pages.

USDOI, Fish and Wildlife Service. 1995. Habitat conservation strategy for Polar Bears in Alaska. USDOI, Fish and Wildlife Service, Alaska Region, Anchorage, Alaska. 119 pages. 